\title{
Experimental Study of the Parameters of High Pulsed Electrical Field Pretreatment to Fruits and Vegetables in Vacuum Freeze-Drying
}

\author{
Yali Wu and Yuming Guo* \\ College of Engineering, Shanxi Agricultural University, Taigu 030801, Shanxi, P.R. China \\ sxauwyla126.com, guoyuming99@sina.com
}

\begin{abstract}
High pulsed electrical field as pre-processing step for fruits and vegetables in the vacuum freeze drying could increase drying rate efficiency and preserve nutritional ingredients in maximum. Moreover, high pulsed electrical field pretreatment has been successfully used to solve practical problems in the vacuum freeze drying, such as energy consumption, high production costs and long drying time etc. The drying experiments were conducted with apples which were pretreated by high pulsed electrical field, and the results showed that high pulsed electrical field pretreatment could increase the drying rate obviously. According to the range analysis, the optimal parameters of high pulsed electrical field for drying were obtained as follows: pulse strength was 1000 $\mathrm{V} \cdot \mathrm{cm}^{-1}$, pulse time was $120 \mu \mathrm{s}$, and pulse number was 30 . By using the above optimal conditions, energy consumption per unit of water was reduced by $17.74 \%$, freeze drying time was shortened by $22.50 \%$, and productivity per unit area was increased by $28.50 \%$ than results of the untreated group. In addition, it was found that the most important physical factors of high pulsed electrical field which affected the vacuum freeze drying were the pulse duration, pulse strength and pulse number.
\end{abstract}

Keywords: high pulsed electrical field, freeze-drying, fruits and vegetables, optimization of process parameters.

\section{Introduction}

Vacuum freeze drying technology can ensure the original taste and preserve nutritional ingredients of fruits and vegetables in maximum, and has extensive application foreground in fruits and vegetables processing industry. But commonly used freezedrying techniques were limited by high energy consumption and long drying times. In general, the drying processes consume an appreciable part of the total energy used in food industry and so, it is very important to develop the new hybrid drying technologies for energy consumption reduction and preserving of food qualities[1]. High pulsed electrical field (HPEF) treatment has been reported to increase the permeability of plant cells[2,3,4]. It could enhance extraction and dehydration processes in

\footnotetext{
* Corresponding author.
} 
fruits and vegetables tissues. The choice of suitable HPEF parameters is determined by application, technological, energy consumption and economical considerations.

The phenomenon of increasing permeability of biological tissue cells after electric field application was called electropermeabilization[5,6]. The viewpoint that the HPEF could affect the permeability of a cell membrane was put forward by Sale et al.[7]. Depending on the electric field strength, duration and number of pulses applied the induced membrane breakdown and subsequent permeabilization could be reversible or irreversible[8]. Alexander et al. reported that the cell membrane permeability was reversible breakdown when the cell size was $50 \sim 120 \mu \mathrm{m}$ and the electric field strength was greater than the critical electric field strength $\left(400 \sim 800 \mathrm{~V} \bullet \mathrm{cm}^{-1}\right)$. Their research showed that the processing time of the cell membrane damaged was varied with the structure of materials. For example, the time of potato cell injured was $0.7 \mathrm{~s}$, but the apple cell was $1.41 \mu \mathrm{s}[9]$. Ade-Omowaye et al. studied the effect of different process parameters and high transmission rate on the dehydration characteristics for paprika. They found that HPEF pre-treatment could increase the cell membrane permeability and improve the drying rate[10]. When a plant was treated with HPEF, the cell membranes were ruptured leading to an increase in permeability of the cell walls and subsequent increase in juice yield[11]. In Weiqin Wang's paper, the HPEF processing experiment was conducted to investigate the changes of drying rate for sweet potato after pretreated by HPEF. The results showed that the weight of treated samples was relatively increased by the osmotic dehydration, the pulse strength and the pulse number had influence on the drying rate[12]. Zhenyu Liu and Yuming Guo reported the condition to ensure the high drying rate and the quality of fruits and vegetables was $1000 \sim 1500 \mathrm{~V} \cdot \mathrm{cm}^{-1}$ pulse strength, $60 \sim 110 \mu$ s pulse duration and $2 \sim 30$ pulse number[13].

Our research group has systematically studied on HPEF pre-treatment to fruits and vegetables for vacuum freeze drying in recent years[14,15,16], such as the influence mechanism of HPEF pre-treatment and optimization of process parameters for HPEF pre-treatment technology. The influence of HPEF pre-treatment on the dehydration characteristics and quality for fruits and vegetables are also studied. Optimization of the freeze drying operation could ensure rapid processing operation yielding an acceptable quality product with less cost. On the basis of above mentioned studies, the drying experiments were conducted, studied the influence mechanism of the HPEF processing, and the optimal parameter combination was obtained by experiments.

\section{Materials and Methods}

\subsection{Materials and Equipments}

Fuji apple was chosen as an object of the investigation. Fuji apples of good and uniform quality were purchased from the local market. The specimens were cut into small pieces approximately $17 \mathrm{~mm}$ long, $17 \mathrm{~mm}$ wide and $10 \mathrm{~mm}$ thick. According to the test scheme, 40 samples were treated each time. BTX ECM 830 square wave electroporation system was used.

The drying tests were performed using an on-line moisture monitoring system was designed by Shanxi Agricultural University of China, which based on the reconfigurable virtual instrument considered the working condition of JDG-0.2 pattern of 
freeze-drying testing machine. All the output data (weight, moisture content and real time) were recorded by the designed monitoring system. The freeze-drying process parameters were set to the temperature was $70{ }^{\circ} \mathrm{C}$, vacuum degree was $40 \sim 45 \mathrm{~Pa}$ in the sublimation process and the temperature was $90{ }^{\circ} \mathrm{C}$, vacuum degree was $30 \sim 35 \mathrm{~Pa}$ in the desorption process, respectively.

\subsection{Experimental Methods}

On the basis of the preliminary experiment results, the orthogonal experiment was conducted with pulse strength, pulse duration and pulse number as the independent variables, energy consumption per unit of water, freeze drying time and productivity per unit area as the experiment indicators (Table1).

In the drying experiments, the value of test indexes was determined as follows: Productivity per unit area $=\mathrm{M}_{\mathrm{d}} / \mathrm{T} /(0.36 \times 0.20)$, Energy consumption per unit of water $=\mathrm{P} /\left(\mathrm{M}_{\mathrm{f}} \times \mathrm{W}\right)$. Where: $\mathrm{M}_{\mathrm{d}}$ was the drying weight, $\mathrm{T}$ was the drying time, $\mathrm{P}$ was power consumption, $\mathrm{M}_{\mathrm{f}}$ was initial mass, and $\mathrm{W}$ was the moisture content.

Table 1. Factors and levels of $\mathrm{L}_{9}\left(3^{3}\right)$ orthogonal design

\begin{tabular}{llll}
\hline \multirow{2}{*}{ Level } & \multicolumn{2}{c}{ Factor } \\
\cline { 2 - 4 } & $\begin{array}{l}\text { A--Pulse strength } \\
\left(\mathrm{V} \cdot \mathrm{cm}^{-1}\right)\end{array}$ & $\begin{array}{l}\text { B--Pulse duration } \\
(\mu \mathrm{s})\end{array}$ & $\begin{array}{l}\text { C--Pulse number } \\
(\text { ind })\end{array}$ \\
\hline 1 & 1000 & 60 & 15 \\
2 & 1250 & 90 & 30 \\
3 & 1500 & 120 & 45 \\
\hline
\end{tabular}

\section{Results and Discussion}

From the table 2 results, the productivity per unit area of the pretreated samples was higher than the untreated samples, the energy consumption per unit of water and the drying time were lower than the untreated samples. The reason was that HPEF pretreatment could cause the cell membrane breakdown occurs and increase the permeability of fruits and vegetables membrane. When electric field was applied to a cell in a suspension, an induced voltage was formed across the membrane owing to the capacitance of membrane. As the voltage was increased, the opposite charges on either side of the membrane were attracted to each other with greater force, and the membrane became thinner. At a sufficiently high voltage, pores were formed in the membrane and the cell ruptured. Therefore, HPEF pretreatment could improve the drying rate, save the drying time and increase the production rate.

But the membrane permeability of the untreated samples was low, the temperature and moisture were not easily evaporated, which led to the collapse phenomenon occurs. The collapse phenomenon would extend the drying time, increase the energy consumption and decrease the production rate. 
Table 2. The $\mathrm{L}_{9}\left(3^{3}\right)$ orthogonal design and data processing

\begin{tabular}{|c|c|c|c|c|c|c|}
\hline \multirow[b]{2}{*}{ Trial number } & \multicolumn{3}{|c|}{ Level } & \multicolumn{3}{|c|}{ Indicator } \\
\hline & $\begin{array}{l}\text { A--Pulse } \\
\text { strength } \\
\left(\mathrm{V} \cdot \mathrm{cm}^{-1}\right)\end{array}$ & $\begin{array}{l}\text { B--Pulse } \\
\text { duration } \\
(\mu s)\end{array}$ & $\begin{array}{l}\text { C--Pulse } \\
\text { number } \\
\text { (ind) }\end{array}$ & $\begin{array}{l}\text { Productivity } \\
\text { per unit area } \\
\left(\mathrm{g} \cdot \mathrm{h}^{-1} \cdot \mathrm{m}^{-2}\right)\end{array}$ & $\begin{array}{l}\text { Energy con- } \\
\text { sumption per } \\
\text { unit of water } \\
\left(\mathrm{kJ} \cdot \mathrm{g}^{-1}\right)\end{array}$ & $\begin{array}{l}\text { Drying } \\
\text { time } \\
\text { (h) }\end{array}$ \\
\hline 1 & 1 & 1 & 1 & 23.46 & 395.20 & 7.18 \\
\hline 2 & 1 & 2 & 2 & 25.32 & 424.88 & 7.00 \\
\hline 3 & 1 & 3 & 3 & 25.34 & 393.35 & 6.83 \\
\hline 4 & 2 & 1 & 2 & 23.60 & 431.53 & 7.18 \\
\hline 5 & 2 & 2 & 3 & 24.00 & 419.09 & 7.27 \\
\hline 6 & 2 & 3 & 1 & 26.60 & 435.38 & 7.07 \\
\hline 7 & 3 & 1 & 3 & 24.08 & 467.44 & 7.37 \\
\hline 8 & 3 & 2 & 1 & 21.38 & 438.45 & 7.57 \\
\hline 9 & 3 & 3 & 2 & 27.12 & 428.87 & 7.00 \\
\hline \multirow{4}{*}{$\begin{array}{l}\text { Productivity } \\
\text { per unit area }\end{array}$} & $\mathrm{K}_{1}$ & 74.22 & 71.14 & 71.44 & \multirow{4}{*}{\multicolumn{2}{|c|}{$\begin{array}{l}\text { Optimal combination } \\
\mathrm{B}_{3} \mathrm{C}_{2} \mathrm{~A}_{1}\end{array}$}} \\
\hline & $\mathrm{K}_{2}$ & 74.20 & 70.80 & 76.14 & & \\
\hline & $\mathrm{K}_{3}$ & 72.58 & 79.06 & 73.42 & & \\
\hline & $\mathrm{R}$ & 1.64 & 8.26 & 4.70 & & \\
\hline \multirow{4}{*}{$\begin{array}{l}\text { Energy } \\
\text { consumption } \\
\text { per unit of } \\
\text { water }\end{array}$} & $\mathrm{K}_{1}$ & 1213.42 & 1299.16 & 1269.02 & \multirow{4}{*}{\multicolumn{2}{|c|}{$\begin{array}{l}\text { Optimal combination } \\
\mathrm{A}_{1} \mathrm{~B}_{3} \mathrm{C}_{1}\end{array}$}} \\
\hline & $\mathrm{K}_{2}$ & 1285.99 & 1282.41 & 1285.28 & & \\
\hline & $\mathrm{K}_{3}$ & 1339.75 & 1257.59 & 1274.87 & & \\
\hline & $\mathrm{R}$ & 126.33 & 41.57 & 16.26 & & \\
\hline \multirow{4}{*}{$\begin{array}{l}\text { Drying } \\
\text { time }\end{array}$} & $\mathrm{K}_{1}$ & 21.01 & 21.73 & 21.82 & \multirow{4}{*}{\multicolumn{2}{|c|}{$\begin{array}{l}\text { Optimal combination } \\
\mathrm{B}_{3} \mathrm{~A}_{1} \mathrm{C}_{2}\end{array}$}} \\
\hline & $\mathrm{K}_{2}$ & 21.52 & 21.84 & 21.18 & & \\
\hline & $\mathrm{K}_{3}$ & 21.94 & 20.90 & 21.47 & & \\
\hline & $\mathrm{R}$ & 0.93 & 0.94 & 0.64 & & \\
\hline
\end{tabular}

Experimental results showed that the most important physical factors of high pulsed electrical field which affected the response value were the pulse duration, pulse strength and pulse number. If taking the productivity per unit area as the indicator, the optimal combination was $\mathrm{B}_{3} \mathrm{C}_{2} \mathrm{~A}_{1}$. If taking the energy consumption per unit of water as the indicator, the optimal combination was $\mathrm{A}_{1} \mathrm{~B}_{3} \mathrm{C}_{1}$. If taking the freeze drying time as the indicator, the optimal combination was $\mathrm{B}_{3} \mathrm{~A}_{1} \mathrm{C}_{2}$. By comprehensive consideration, the optimal parameters of HPEF processing was $\mathrm{B}_{3} \mathrm{~A}_{1} \mathrm{C}$, namely the pulse strength was $1000 \mathrm{~V} \cdot \mathrm{cm}^{-1}$, the pulse duration was $120 \mu$ s and the pulse number was 30 . 


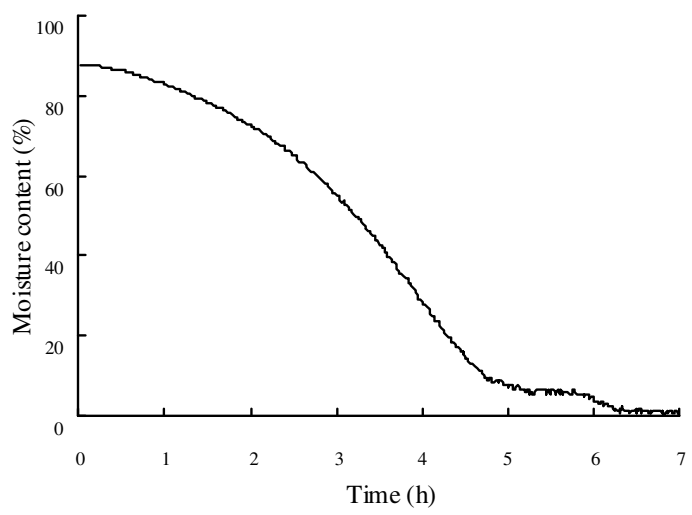

Fig. 1. Changes in moisture content of pretreated samples by HPEF

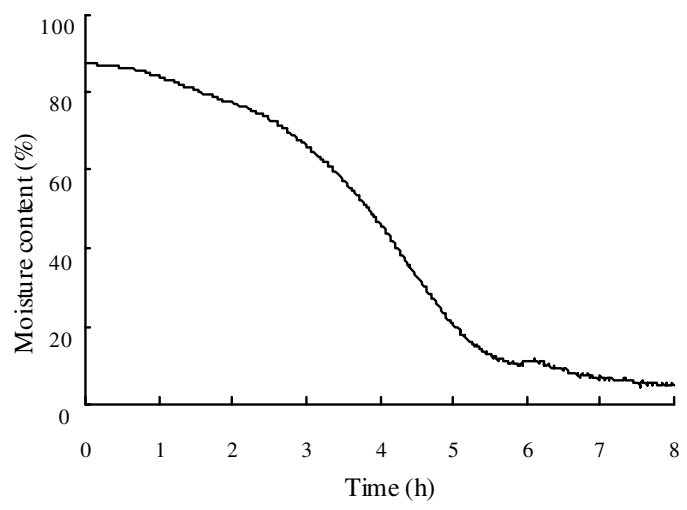

Fig. 2. Changes in moisture content of untreated samples

Fig.1 and Fig. 2 showed the change in moisture content of apple samples. From the Fig.1 and Fig.2, the moisture content of the HPEF pretreated samples could reach about $0.01 \%$ after drying, but the untreated samples was essentially kept constant when the moisture content descended to 5\%. Therefore, the result of completely dry could be achieved by HPEF pretreatment. The drying time of apples which were pretreated by HPEF was shorted more than 1 hour than untreated apples, and the water content was decreased rapidly in the sublimation process, while those was opposite for the untreated group.

\section{Verification Test}

In order to ensure the feasibility of optimal processing, the verification test was conducted using the optimum technological parameters $\left(1000 \mathrm{~V}^{\circ} \mathrm{cm}^{-1}, 120 \mu \mathrm{s}, 30\right)$. The results were listed in Table 3 . It could be concluded from the comparison and analysis 
that all values of the optimal scheme were superior to results of the orthogonal test. The results indicated that the choice of parameters was reasonable. With the optimized processing conditions, productivity per unit area was increased by $28.50 \%$, energy consumption per unit of water was reduced by $17.74 \%$, and freeze drying time was shortened by $22.50 \%$ compared with untreated.

Table 3. Results of the verification \& untreated tests

\begin{tabular}{llll}
\hline Trial & $\begin{array}{l}\text { Productivity per unit } \\
\text { area }\left(\mathrm{g} \cdot \mathrm{h}^{-1} \cdot \mathrm{m}^{-2}\right)\end{array}$ & $\begin{array}{l}\text { Energy consumption per } \\
\text { unit of water }\left(\mathrm{kJ} \cdot \mathrm{g}^{-1}\right)\end{array}$ & Drying time $(\mathrm{h})$ \\
\hline Untreated group & 22.63 & 473.38 & 8.00 \\
Verification test & 29.08 & 389.41 & 6.20 \\
\hline
\end{tabular}

\section{Conclusion}

By considering the result above, the main conclusions drawn from the study were: (i) The pulse duration, pulse strength and pulse number were in order of importance among the obtained parameters. (ii) The optimum parameters were obtained as follows: pulse strength was $1000 \mathrm{~V} \cdot \mathrm{cm}^{-1}$, pulse duration was $120 \mu \mathrm{s}$, and pulse number was 30 . With the optimized processing conditions, productivity per unit area was increased by $28.50 \%$, energy consumption per unit of water was reduced by $17.74 \%$, and freeze drying time was shortened by $22.50 \%$ than results of the untreated groups. (iii) HPEF could increase the cell membrane permeability and intracellular water was more easily diffused out of the cells, so the drying rate was improved.

HPEF as pre-processing for drying is important to solve the processing problems in the vacuum freeze drying, such as energy consumption, processing cost and low drying rate etc. The optimal vacuum processing technology of freeze-drying will provide support for exploring low energy consumption in the freeze-dried process for fruits and vegetables.

Acknowledgments. Funding for this research was supported by National Natural Science Foundation of China (No. 30771242).

\section{References}

1. Chou, S.K., Chua, K.J.: New Hybrid Drying Technologies for Heat Sensitive Foodstuffs. Trends in Food Science and Technology 12, 359-369 (2001)

2. Geulen, M., Teichgräber, P., Knorr, D.: High Electric Field Pulses for Cell Permeabilisation (ZFL) Z. Lebensmittelwirtschaft 45, 24-27 (1994)

3. Knorr, D., Geulen, W., Grahl, T., Sitzmann, W.: Food Application of High Electric Field Pulses. Trends Food Sci. Technol. 5, 71-75 (1994)

4. Knorr, D., Angersbach, A.: Impact of High Electric Field Pulses on Plant Membrane Permeabilization. Trends Food Sci. Technol. 9, 185-191 (1998)

5. Teissie, J., Eynard, N., et al.: Electropermeabilization of Cell Membranes. Advanced Drug Delivery Reviews 35(1), 3-19 (1999) 
6. Angersbach, A., Heinz, V., Knorr, D.: Evaluation of Process-Induced Dimentional Changes in the Membrane Structure of Biological Cells Using Impedance Measurement. Biotechnology Progress. 18(3), 597-603 (2002)

7. Sale, A.J.H., Hamilton, W.A.: Effects of High Electric Fields on Microorganisms: I Killing of Bacteria and Yeasts. Biochimica et Biophysica Acta. 148(3), 781-788 (1967)

8. Benz, R., Zimmermann, U.: Relaxation Studies on Cell Membranes and Lipid Bilayers in the High Electric Field Range Bioelectrochem. Bioenerg. 7, 723-739 (1980)

9. Benz, R., Zimmermann, U.: High Electric Field Effects on the Cell Membranes of Halicystic Parvular. Planta 152(4), 314-318 (1981)

10. Ade-Omowaye, B.I.O., Rastogi, N.K., et al.: Osmotic Dehydration of Bell Peppers: Influence of High Intensity Electric Field Pulses and Elevated Temperature Treatment. Journal of Food Engineering 54(1), 35-43 (2002)

11. Eshtiaghi, M.N., Knorr, D.: High Electric Field Pulse Pretreatment: Potential for Sugar Beet Processing. Journal of Food Engineering 52, 265-272 (2002)

12. Wang, W., Gai, L., Wang, J.: The Effect of High Pulsed Electrical Field Pretreatment to Sweet Potato for Dehydration. Transactions of the Chinese Society for Agricultural Machinery 36(8), 154-156 (2005)

13. Liu, Z., Guo, Y.: The Effect of High Pulsed Electrical Field Pretreatment to Fruit and Vegetable for Dehydration. Journal of Agricultural Mechanization Research 31(12), 9-12 (2008)

14. Guo, Y., Yao, Z., Cui, Q.: Combined Experimental Study on the Effects of the Operational Parameters on Energy Consumption of Sublimation-Drying During Vacuum FreezeDrying. Transactions of the CSAE 20(4), 180-184 (2004)

15. Cui, Q., Guo, Y., et al.: Design and Test of On-Line Measurement System for the Moisture Content of the Freeze-Drying Materials. Transactions of the Chinese Society for Agricultural Machinery 39(4), 91-96 (2008)

16. Liu, Z., Guo, Y.: BP Neural Network Prediction of the Effects of Drying Rate of Fruits and Vegetables Pretreated by High-Pulsed Electric Field. Transactions of the CSAE 25(2), 235-239 (2009) 